\title{
ШКІЛЬНИЙ САД - СКЛАДОВА ОСВІТНЬО-ВИХОВНОГО СЕРЕДОВИЩА ШКОЛИ СУХОМЛИНСЬКОГО
}

\begin{abstract}
Анотація. В статті охарактеризовано поняття «освітньо-виховне середовище» крізь призму теми дослідження; вичленено шкільний сад як важливий компонент в структурі педагогічної системи В. Сухомлинського. 3'ясовано, що шкільний сад постає у ній як символ школи взагалі, та особливо школи, керованої Сухомлинським, й номінується педагогом центром освітньо-виховного середовища, в якому живуть i розвиваються учні. Розкрито змістове наповнення поняття «шкільний сад», яке, за Сухомлинським, включає у себе власне сад - організовану територію 3 плодовими деревами і кущами, а також шкільну та дослідну ділянки, зелену лабораторію, грядки, теплиці тощо. Доведено, що в школі Сухомлинського шкільний сад використовувався для розбудови i більш продуктивного налагодження фізичного, морального, розумового, трудового, естетичного виховання школярів різного віку і статі, з'ясовано зміст кожного 3 напрямів, окреслено застосовувані форми й методи навчання i виховання. Зроблено висновок про багатофункціональність явища «шкільного саду» школи Сухомлинського, яке, залежно від контексту, виступає комплексним методом навчання і виховання, своєрідною формою організації педагогічного процесу, метою загальновиховного процесу, опоетизованим ідеалом, для досягнення якого застосовується гармонія педагогічних впливів.

Аналіз проведено крізь призму мети і завдань Нової української школи як додатковий важливий аргумент i ресурс для розбудови природного активного i діяльнісного освітньо-виховного середовища, дружнього до дитини.

Ключові слова: В. Сухомлинський, освітньо-виховне середовище, шкільний сад, Павлиська школа, виховання, освіта, Нова українська школа.

Постановка проблеми. У сучасному світі все чіткіше усвідомлюється, що освіту, формування гармонійно розвиненої особистості не можна розглядати як засвоєння певної бази знань, суто шкільну педагогіку. Вони $\epsilon$ результатом впливу широкого спектру різнорідних факторів, і серед них одне із чільних місць посідає навколишнє середовище. У педагогічних розвідках все частіше використовується поняття «освітньо-виховне середовище», що охоплює дуже широкий спектр чинників, та підкреслює факт множинності впливів на особистість, що визначають, зрештою, розвиток дитини, іiї освіту та виховання.

Питання організації та педагогічного впливу освітньо-виховного середовища на дітей стоїть нині на порядку денному як для науковців, так і вчителів у зв'язку 3 процесами реформування закладів освіти, першими кроками діяльності Нової української школи, яка розглядає освітньо-виховне середовище як один зі своїх головних компонентів. У зв'язку з цим виникає потреба ознайомлення не лише із нинішнім станом вивчення проблеми, а й його перспективним минулим, що не втратило своєї актуальності.
\end{abstract}


Мета статті: цілісно проаналізувати підходи В. Сухомлинського до такої важливої методичної складової освітньо-виховного середовища як шкільний сад, його роль і значення в системі різнобічного впливу на школярів у керованій ним школі.

Аналіз останніх досліджень 3 проблеми. Наукових розвідок, присвячених шкільним садам як складовим освітньо-виховного процесу школярів, досить мало. Однак підкреслимо, що нині садам як простору освіти та виховання приділяється значна увага директорами шкіл, учителями-практиками; вони відроджуються як в Україні, так і в зарубіжжі. Приміром, ця традиція відроджена в ЗСШ I-ІІІ ступенів с. Ст. Чорторийськ Маневицького району на Волині, де закладання саду стало загальношкільним святом (Шкільний сад за.). Екологічні грядки заклали й учні Ріпкинської школи № 2 на Чернігівщині, які у лютому 2019-го року виграли 19 тисяч євро міжнародного благодійного фонду «Зелений Хрест» для створення виробничих інкубаторів «Шкільний сад». Учні будуть самі обробляти грядки та вирощувати на них овочі, щоб ознайомитись із технологіями органічного сільського господарства і підприємництва (Шкільний сад у Ріпках: учні школи №2 заклали грядки, на яких самі вирощуватимуть овочі). Цікаву роботу зі створення шкільного саду описано в статті польських педагогів «Шкільний сад як навчально-дослідницьке середовище сучасної школи: польський досвід». У статті йдеться про те, як у початковій школі та гімназії с. Посквітув створено дружнє освітнє середовище для учнів у вигляді мальовничих садів за тематичним принципом 3 метою поєднання в освітньо-виховному процесі місцевих традицій, загальної історії, культури та природи. У школі створено Біблійні сади, Середньовічні сади, Сад прабабці та сади із цілющими травами (Знаміровська, 2012). Вітчизняні науковці до цієї теми не зверталися.

Виклад основного матеріалу дослідження. Питання організації освітньовиховного середовища цікавило педагогів і психологів ще на початку XX ст. Так, ще Л. С. Виготський стверджував, що повноцінне освітнє середовище не $\epsilon$ елементом психіки, але розвиток психіки людини не можна розглядати поза зв'язком 3 навколишнім середовищем. Він наголошував на важливій ролі соціального середовища (терміни «освітньо-виховне середовище» або «освітне середовище» тоді не застосовувалися) для розвитку дитини. За його твердженням, «...соціальне середовище $\epsilon$ джерелом виникнення всіх специфічно людських властивостей особистості, поступово набутих дитиною, або джерелом соціального розвитку дитини, яке відбувається в процесі реальної взаємодії ідеальних та існуючих форм» (Выготский, 1984).

Однак, використовуючи поняття «освітньо-виховне середовище», більшість сучасних психологів підкреслюють, що навчання, виховання і розвиток істотно детерміновані соціокультурними умовами, предметно-просторовим оточенням, характером міжособистісної взаємодії і іншими середовищними чинниками.

Відповідно до такого підходу під освітньо-виховним середовищем розуміється система педагогічних і психологічних умов та впливів у соціальному і предметнопросторовому вимірі, які створюють можливість для розкриття як вже наявних здібностей і особистісних особливостей учнів, так і тих інтересів і здібностей, що ще не проявилися повною мірою (Приходько, 2010).

Особливе місце у такому підході посідає природне довкілля. I це не є вимогою останніх років. Про важливість середовищного підходу наголошували практично усі представники реформаторської педагогіки у європейських країнах і США наприкінці XIX - початку XX ст., які створювали альтернативні навчальні заклади, що нині стали реальністю шкільного життя в різних країнах світу. Серед них школи М. Монтесорі, Вальдорфські школи, школа Самергіл О. Ніла та інші. Долучимо ж до когорти педагогів, які багато зробили для розуміння ролі й значення освітньо-виховного середовища, і Василя Олександровича Сухомлинського.

Розглянемо саме шкільний сад як одну із важливих складових середовищного підходу в педагогічній системі В. Сухомлинського. Тема саду як простору під 
відкритим небом, дослідної ділянки як майданчика наукової, трудової, пізнавальної діяльності звучить майже в усіх педагогічних та в багатьох художніх творах педагога. На його думку, естетичне та моральне виховання взагалі неможливе без природи, без саду, Саду дитинства. Вважаємо, що Сад у всесвіті Сухомлинського перегукується 3 біблійним Садом, де народжується Душа Людини. Згадаймо його статті з такими промовистими назвами: «Сад для людей» (Сухомлинський, 1963), «Зростуть квіти дивної краси» (Сухомлинський, 1964), «Стежка до квітучого саду» (Сухомлинський, 1969).

У статті ми послуговуємося поняттям «шкільний сад», що включає в себе всі перелічені вище складові і відповідає притаманному педагогу образному стилю.

Найбільш грунтовно тема саду представлена у праці «Павлиська середня школа», де «узагальнено багаторічний досвід навчально-виховної роботи Павлиської середньої школи. Розповідаючи про зусилля педагогічного колективу у вихованні всебічно розвиненої людини, автор прагнув показати цю працю по можливості з усіх боків, не тільки роз'яснити методи, що застосовуються, а й розкрити їх внутрішні зв'язки та взаємозв'язки» (Сухомлинський, 1977, с. 7).

У семи розділах твору детально описані життя і робота вчительського та учнівського колективів, дидактичні та методичні складові педагогічного пошуку впродовж тридцяти років. Починаючи з опису роботи педагогічного колективу i створення матеріальної бази школи та самого середовища, що оточує дітей, В. Сухомлинський переходить до висвітлення методів виховання: фізичного, морального, розумового, трудового та естетичного - тих складових, що формують гармонійно розвинену особистість. А шкільний сад та дослідна ділянка посідають у цій системі одну із провідних ролей.

Матеріальну базу школи В. Сухомлинський розглядав «у нерозривній єдності 3 обстановкою, до якої входять природа, праця і суспільна діяльність навколишніх людей. Багато предметів, що знаходяться тут, створені самими школярами або їх старшими товаришами і в певному розумінні одухотворені їх любовним ставленням, стають дорогими для кожного з них, поєднуються в їхній емоційній пам'яті з подіями, людськими відносинами, почуттями, переживаннями» (1977, с. 89). Павлиська школа розташована на ділянці землі площею у 5 гектарів, недалеко ліс, сільськогосподарські угіддя, річка та став. На шкільній ділянці був розбитий сад, виноградник та теплиця, створені руками учнів та вчителів. Не оминали своєю увагою вихованці і позашкільну територію. Було закладено кілька полезахисних дібров, вирощено бузковий гай, за 20 років зусиллями школярів 40 гектарів неродючого, глинястого грунту перетворилися на ниви і сади. Педагог неодноразово наголошував, що «школа майбутнього повинна якнайповніше використовувати для гармонійного розвитку людини все, що дає природа і що може зробити людина для того, щоб природа служила їй» (1977, с. 92).

Один з розділів книги має назву «Шкільна ділянка і ії виховна роль». Що ж являв собою шкільний сад у Павлиській школі? Василь Сухомлинський намагався, аби у саду росли всі види плодових дерев, що культивувалися в Україні, рідкісні для тієї місцевості дерева та кущі, виноградник, теплиці 3 централізованим опаленням та водогоном, зелена лабораторія. У двох теплицях вирощували квіти та овочі, цитрусові культури, проводили експерименти. У зеленій лабораторії працювали наукові та юннатівські гуртки, ставилися досліди; іiі було обладнано сушильною камерою, погребом, де проводили досліди, які потребують зниженої температури, шафами для гербаріїв, колекцій грунтів та мінеральних добрив. Поряд із теплицями були облаштовані парники. До «шкільного саду» входили кролятник та пасіка. На окремих ділянках було розбито персиковий гай, каштанову та ялинову алеї, навчально-дослідну ділянку, де вирощували зернові і технічні культури, був плодорозсадник, дитяча фабрика добрив. А ще на території був гараж для двох навчальних машин і тракторів. I майже все це було побудовано руками школярів (1977, с. 108-112). Все це можна 
умовно назвати Шкільним садом, і В. Сухомлинський використовував його в усіх напрямах навчально-виховної роботи.

Коротко зупинимося на цих напрямах. Педагог неодноразово наголошував, що розподіл фізичної і розумової діяльності та відпочинку, режим сну є важливою умовою здоров'я дитини, запорукою їі гармонійного розвитку та шкільної успішності. А відтак велика кількість дерев у шкільному саду була такою собі «фабрикою кисню» $\mathrm{i}$ місциною, де навіть у спекотний день було прохолодно. Учні молодших класів проводили у закритому приміщенні не більше трьох годин, решту часу було відведено для уроків на природі.

Зміцненню здоров'я дитини сприяє фізична праця та фізичне виховання. Ось як це характеризував В. Сухомлинський: «Фізична праця відіграє таку саму важливу роль у формуванні фізичної досконалості, як і спорт. Без здорової втоми людині не може бути повною мірою доступна насолода відпочинком» (1977, с. 137). Школярі різного віку були задіяні у різноманітних видах фізичної праці упродовж усього шкільного життя. Вони фізично розвинені, здорові, «характерною рисою їх фізичного розвитку $є$ поєднання стрункості, краси постави, пластичності рухів і фізичної сили» (1977, с. 138). Починаючи 3 першого класу, діти виконували посильну роботу в саду та на шкільній ділянці - доглядали за деревами та виноградом, збирали насіння, вирощували саджанці. Учні середнього віку не менше 2-3 годин працювали фізично на свіжому повітрі, старші школярі два-три тижні жили і працювали в полі на косовиці або ж зборі врожаю.

Василь Олександрович наголошував, що проблема вільного часу та відпочинку дітей $є$ не менш важливою, ніж період навчання, що відпочинок має бути активним, дієвим. Діти під час канікул ходили у туристичні походи, де повністю самі себе обслуговували, відпочивали у самодіяльному таборі, облаштованому у плодовому саду. «Відпочинок поєднується 3 посильною працею», - зазначав педагог. - <..> «Відпочиваючи, діти доглядають за деревами, збирають урожай. Інші загони розміщуються в лісі: діти охороняють дерева, збирають рослини для гербаріїв і колекцій, заготовляють насіння» (1977, с. 143).

Загальновизнано, що вся педагогічна система Сухомлинського це, насамперед, виховання моральних цінностей. Педагог вважав, що моральне виховання починається із раннього дитинства, і саме школа покликана прищеплювати маленькій людині загальнолюдські норми моралі, а саме: кожен твій вчинок позначається на людях, серед яких ти живеш; відповідай добром на добро; поважай людську працю; допомагай слабким і беззахисним; поважай батька і матір; не будь байдужим до зла; борись проти обману та несправедливості. Ці цінності актуальні у всі часи, але основною метою морального виховання В. Сухомлинський вважав виховання людинигромадянина, відповідальної за себе, за людей, які ії оточують, за вулицю, село, місто, землю, на якій вона живе, за країну в цілому. Які ж методи у царині морального виховання пропонує досвід Павлиської школи з огляду на тему нашого дослідження?

Тут існувало безліч традицій, які прищеплювали дітям певні поведінкові патерни, i серед них різноманітні свята та знакові події: Свято матері, Свято дівчат, Свято квітів, Свято птахів, Свято першого дзвоника, коли школярі готували подарунки або частування. Це були квіти, гілочки дерев, фрукти, вирощені у шкільному саду власними руками. Особливе місце в житті школи посідали трудові традиції: виготовлення наочних посібників для біологічного кабінету, прикрашання класів та шкільного подвір'я, Тиждень саду, День першого снопа, Свято першого хліба, літня косовиця тощо. Тиждень саду проходив навесні та восени, коли діти саджали дерева, готували ями та добрива, обмінювалися саджанцями, восени ділилися плодами своєї праці 3 рідними та односельцями. Цей процес був довготривалим і вимагав від педагогів терпіння і уваги: «Ми добиваємося, щоб кожна дитина піклувалася про квіти і рослини, про птахів і тварин, про рибок в акваріумі <..> дитина саджає на домашній присадибній ділянці яблуню матері, яблуню бабусі, яблуню батька, яблуню дідуся. 
Вона доглядає деревця (звичайно, про це їй доводиться часто нагадувати, буквально вести за руку). Настає день, коли на цих деревах достигають плоди, дитина несе їх своїм рідним (цього також треба навчити, тисячу разів нагадати). Якщо вам вдалося добитися того, що ці миттєвості стали для дитини найрадіснішими в іiї житті, отже, ви вклали в її серце моральні цінності» (Сухомлинський, 1977, с. 149-150).

Кожен куточок шкільного саду Школи Сухомлинського плекав культуру почуттів, те, що сучасники називають «емоційним інтелектом», що є нині одним з головних завдань формування сучасної людини. Декілька прикладів: квартира директора знаходилася у приміщенні школи і мала вихід до алеї. За мовчазною домовленістю діти ніколи не зчиняли галасу, не грали у цьому куточку, натомість вчителі не порушували меж куточків саду, потрібних дітям для усамітнення. Кожен 3 них належав певній віковій групі школярів. Трояндові та мальвові, плакучих верб - алеї юності. «Ми, вчителі, дбайливо оберігаємо право підлітків, юнаків і дівчат на своє глибоко особисте, інтимне, недоторкане. Учитель вважає безтактним піти до куточка, що став традиційним місцем самотності старшокласників. На подяку за це старшокласники також оберігають наше право на спокійний відпочинок і самоту. <..> Основа стосунків між цими колективами - взаємна повага педагогів і вихованців, особливо повага до почуттів один одного», - писав педагог (Сухомлинський, 1977, с. 115). I таких прикладів безліч. Діти навчаються поважати почуття інших людей, не виконувати марудну роботу з примусу, але привчаються облаштовувати своє життя і навколишнє середовище згідно 3 моральними переконаннями: підв'язати зламану гілку, полити дерева у спеку, піклуватися про поранених птахів і тварин, ділитися плодами своєї праці зі старшими та самотніми, облаштовувати не лише територію своєї школи, але вулиці, села, того, що зараз називають ком'юніті. Поступово ці дії входять у звичку і формують стиль життя і моральні переконання, усталені моделі поведінки.

Щодо розумового виховання, то у В. Сухомлинського була своя, роками вивірена методика, що згодом знайшла відображення у багатьох його творах - уроки мислення і Школа під голубим небом. Ось його педагогічне кредо: «В дошкільному і молодшому шкільному віці відбувається формування вдачі, мислення, мовлення людини. Може бути, все те, що приходить у розум і серце дитини з книжки, з підручника, з уроку, якраз і приходить лише тому, що поряд із книгою $є$ навколишній світ - природа, поля і луки, пісня жайворонка та нічні шерехи, завивання холодного зимового вітру і химерні візерунки на шибках, щойно розквітлий пролісок й пахощі пробудженого листя; тому, що навколо маленької людини добро і зло, які вона бачить у навколишньому світі, і в цьому світі робить свої нелегкі кроки на довгому шляху від народження до моменту, коли зможе сама відкрити і прочитати книгу» (Сухомлинська, с. 49-50).

Від уроків природи, від шкільного саду, від «Школи радості» бере початок вся художня спадщина В. Сухомлинського, де він письменник i казкар. Практика вдумливого спостереження за явищами природи, їх аналіз, складання казок разом із дітьми, на думку педагога, давали потужний поштовх до розвитку мислення і мови. 3 перших днів шкільного життя малюків вчили спостерігати явища природи, милуватися іiї красою, думати про те, що вони бачать, говорити, про що вони думають, складати і записувати оповідання на основі побаченого. Ось декілька пропонованих тем творів для молодших школярів: «Шкільний сад», «Квіти біля школи», «Як ми приваблюємо пташок», «Перша весняна квітка», «Наш виноградник», «Осінь у саду», «Коли цвітуть яблуні», «Моє цуценя», «Моє кошеня», «Моє деревце» тощо. Той факт, що літературна спадщина та методики розвитку мислення у дошкільників та молодших школярів широко використовуються сучасними педагогами, доводить правильність педагогічного експерименту.

Педагог наголошував, що перш за все мета розумового виховання - не зубріння, не заучування сухих «книжкових» знань, а формування світогляду. Так от, шкільний сад, шкільна ділянка, ліс, луки, вся навколишня природа покликані стати майданчиком для 
розумового розвитку і формування гармонійної людини. Ось що він писав 3 цього приводу: «У зв'язку з цим найважливішим елементом розумового виховання стають: при вивченні предметів природничого циклу - продуктивна праця, дослідження, експеримент; при вивченні гуманітарних предметів - самостійне вивчення життєвих явищ, літературних джерел, літературно-творчі спроби» (Сухомлинський, 1977, с. 207). Тобто, у зелених класах в Павлиській школі вивчали природознавство, біологію, фізику, хімію, астрономію, математику, проводили уроки розвитку мовлення, літератури, образотворчого мистецтва, ручної праці.

Розумове виховання у поєднанні з трудовим із залученням шкільного саду в широкому його розумінні в Школі Сухомлинського проводилося системно: вже у початковій школі учні мали усвідомити різницю між живим і неживим, осмислити поняття про рослину і грунт, про процеси у природі, що впливають на розвиток рослин та живих організмів. У середніх класах учні досліджували складні біохімічні процесу в грунтах. Старшокласники працювали на навчально-дослідній ділянці, вивчаючи такі складні процеси як хімічні і біологічні способи прискорення росту та розвитку різноманітних сільськогосподарських культур (Сухомлинський, 1977, с. 217). В. Сухомлинський вважав, що розумовий розвиток, здобуття наукових знань покликані не лише сформувати певний світогляд, а й широко використовуватися в практичній діяльності, у праці, у виборі майбутньої професії. Завдяки різноманітним видам діяльності, виконанню завдань на розвиток мислення, розумовому аналізу результатів спостережень, дослідженню сутності явищ та закономірностей природи, причинно-наслідкових зав'язків вчителі школи простежували інтереси та схильності дітей. «У кожної дитини думка розвивається своєрідними шляхами, - переконаний педагог, - кожна розумна і талановита по-своєму. Немає жодної нормальної дитини нездібної, бездарної» (1977, с. 240).

Надважлива роль у Школі Сухомлинського приділялася саме трудовому вихованню, яке педагог розглядав як головний елемент естетичного, морального та інтелектуального виховання, гармонійно зв'язуючи їх у цілісну систему. Основними видами суспільно корисної праці, що їх виконували учні, і яким навчалися, були сільськогосподарські та природоохоронні. Серед принципів трудового виховання, якими послуговувався педагогічний колектив, були такі: виявлення індивідуальності в праці; ранне залучення до продуктивної праці; різноманітність видів праці; постійність, безперервність праці; творчий характер праці; посильність трудової діяльності тощо. Левова частка трудових звитяг школярів проходила у шкільному саду (Сухомлинський, 1977, с. 301-309). I там «раннє включення в трудову діяльність дає змогу добитися того, що в 10-12-річному віці дитина в нас уміє обробляти грунт і готувати його під зернові й технічні культури, вирощувати і збирати врожай цих культур, вирощувати плодові дерева, заготовляти добрива і вносити їх у грунт, перетворювати неродючий грунт у грунт високої родючості» (Сухомлинський, 1977, с. 307). Багато уваги в школі приділялося суспільному значенню трудового виховання, співвідношенню навчальних і виховних цілей, розумових і фізичних зусиль, а також результатам трудової діяльності та оплаті праці. До прикладу, школа мала право продавати фрукти та виноград, вирощені учнями, і на ці кошти діти їздили на екскурсії до інших міст.

Праця учнів не була ані нудною, ані примусовою. Натомість педагоги докладали максимум зусиль, аби зробити трудове виховання в освітньому середовищі, а особливо в саду, пізнавальним, орієнтованим на науково-технічний прогрес. Під керівництвом учителя фізики учні зробили механічний полив, i «коли поливання відійшло на другий план, діти почали думати над тим, як поліпшити склад грунту, щоб прискорити розвиток окремих органів і всієї рослини, як забезпечити сталу вологість повітря, якими способами проводити позакореневе підживлення тощо. У них народився новий задум: поливання кожної окремої рослини можна замінити штучним дощем. <..> Старші школярі почали іонізувати воду» (Сухомлинський, 1977, с. 336-337). I таких 
прикладів можна навести дуже багато. Не буде зайвим підкреслити роль шкільного саду у виконанні колективних трудових завдань та змагання як форми розвитку творчих здібностей, що об'єднують та зближують шкільну громаду, оздоровлюють стосунки у дитячому колективі.

Основою естетичного виховання у шкільному саду Василь Сухомлинський вважав споглядання, спостереження, замилування красою природи, що оточує дитину, iii вивчення, збереження, дбайливе ставлення до світу «живого і прекрасного». 3 перших днів шкільного життя вчителі у саду вчать дітей розуміти красу навколишнього світу. «Важливу роль у нашій системі естетичного виховання відіграють подорожі в світ краси - екскурсії і походи, спостереження, аналіз явищ природи. <..> Справжнє свято для дітей - цвітіння садів. Рано-вранці ми приходимо на шкільну ділянку, йдемо в сад, захоплюємося білим, рожевим, оранжевим убранням дерев, слухаємо дзижчання бджіл. «Не можна довго спати в ці дні. - вчимо ми дітей Можна проспати красу. < ..> На цю красу вона сама [дитина] не зверне уваги, якщо їй цього не показати, не розповісти про це» (1977, с. 370, 372-373).

Квінтесенцією поглядів педагога на естетичне виховання можна вважати його художньо-літературний доробок: 31500 казок та оповідань чимало про світ природи і краси, написаних разом з учнями на уроках серед природи, у шкільному саду (уклад. Сухомлинська, 2018).

Підсумовуючи наше дослідження, наголосимо, що В. Сухомлинський не лише вважав усі методи трудового, розумового, морального та фізичного виховання нерозривно пов'язаними між собою, вони об'єднувалися у предметно-просторовому вимірі, спиралися на пробудження і розвиток мислення, емоційно-ціннісного i активного, діяльнісного самовираження кожної дитини. Ось що він писав: «Ми прагнемо, щоб у дитини з малих років виховувалася емоційно-естетична чутливість до того, що і як вона зробила, що думають і говорять про іiї працю інші, як оцінює iіi працю колектив. Праця входить у духовне життя дитини лише тоді, коли вона відчуває красу того, що створила для людей, - лише в цьому разі вона відчуває відмінність між добрим і поганим. У кожної дитини на шкільній садибі, в саду, на присадибній ділянці батьків $є$ куточок, де вона створює щось красиве, де її праця прикрашає землю» (1977, c. 361).

Висновки і перспективи подальших розвідок. Що саме 3 досвіду включення шкільного саду в діяльність школи в Павлиші можуть використати сучасні педагоги? На нашу думку, тут є багато перспектив, як футуристичних, так і цілком практичних та здійсненних.

Сьогоднішнім учителям та педагогам майбутнього у період розгортання ідей та положень НУШ (Новий освітній простір - символи змін), особливо в умовах переповнення шкіл у великих міських агломераціях, доцільно було б звернутися до спадщини В. Сухомлинського щодо використання найближчого освітнього середовища - від винесення закладів освіти у передмістя, створення опорних шкіл, територія яких дозволяла б розбити у школі сад та дослідну ділянку, до використання мінімалістичних форм, міні-садів, «садів на підвіконні», маленьких пришкільних ділянок тощо, які, втім, можуть принести велику користь в освітньому процесі.

Також було б корисно запозичити досвід використання шкільного саду у тих аспектах освітньо-виховного процесу, стан яких нині $є$ незадовільним, і не лише в Україні.

Це стосується фізичного виховання. За наявними статистичними даними фізична культура, фізичне виховання школярів знаходяться у вкрай незадовільному стані і мають тенденцію до погіршення. Сучасні діти безліч часу витрачають на гаджети та віртуальне життя в інтернеті. Це погано відображається на здоров'ї та психічному стані дитини. I тут ідея та продумана концепція Шкільного саду має всі підстави до широкого використання. Така ж тенденція прослідковується і в трудовому вихованні, на яке зараз в Україні не звертається належної уваги. Досвід школи Сухомлинського, а 
саме шкільного саду, можна використати при формуванні у школярів навичок самообслуговування, облаштування свого життєвого простору, вибору професії тощо.

Ми переконані, що напрацювання педагогів школи Сухомлинського перегукуються з найсучаснішими тенденціями в освіті, з тим, що потребує покоління Z. 3 виступу американського підлітка Логана Ла Планта 3 теорією Hackschooling: сучасні діти хочуть бути щасливими, спілкуватися з природою, уникати стресу i вивчати «світ», «зламуючи» дисципліни, в залежності від потреби та зацікавленості у них (Hackschooling makes me happy).

I найголовніше, на наш погляд, - шкільний сад, єднання 3 природою, догляд за рослинами та тваринами покликані формувати світогляд, емоційний інтелект, поведінкові патерни, спрямовані на збереження довкілля, формування середовища, дружнього до людини, рослин та тварин.

\section{СПИСОК ВИКОРИСТАНИХ ДЖЕРЕЛ}

Шкільний сад за [online]. Режим доступу: http://man-jsvita.org,ua/news/shkilniy-sadza [дата останнього звернення 20.07.2019]

Шкільний сад у Ріпках: учні школи №2 заклали грядки, на яких самі вирошуюватимуть овочі. [online]. Режим доступу: http://cn.suspilne.media/news/17760 [дата останнього звернення 21.07.2019]

Знаміровська, Н. (2012). Шкільний сад як навчально-дослідницьке середовище сучасної школи: Польський досвід. Постметодика. № 2. С. 22-25 [online]. Режим доступу: http://nbuv.gov.ua/UJRN/Postmetodyka_2012_2_6 [дата останнього звернення 25.07.2019]

Выготский, Л. Собрание сочинений в $6 \mathrm{~m}$. Т. 4. Детская психология [под ред. Д. Б. Эльконина]. Москва, 1984. 432 с.

Приходько, Катерина. (2010). Середовищний підхід до навчання і виховання молоді. Шлях освіти. № 3. С. 22-27.

Сухомлинський, В. (1963). Сад для людей. Рад. Україна. 20 берез.

Сухомлинський, В. (1964). Зростуть квіти дивної красию. Кіровогр. правда. 1 січ.

Сухомлинський, В. (1969). Стежка до квітучого саду. Літ. Україна. 26 верес.

Сухомлинський, В. (1977). Павлиська середня школа. Вибрані твори: В 5 m. Т. 4. Київ : Радянська школа. С.7-390.

Сухомлинський, В. Серие віддаю дітям : [нове прочитання] / уклад. та авт. вступ. ст. «У пошуках справжнього», с. 5-22, О. В. Сухомлинська] (2012). [Харків] : Акта. $537 \mathrm{c}$.

Сухомлинський, В. Я розповім вам казку... Філософія для дітей. Василь Сухомлинський ; уклад. Сухомлинська О. В. (2018). Харків : ВД «ШКОЛА». 576 с.

Новий освітній простір=символи змін. Рекомендації. [online]. Режим доступу: http:/mon.gov.ua/storage/app/media/zagalna\%20serednya/nop/5noprekomend22.pdf [дата останнього звернення 20.07.2019]

Hackschooling Makes Me Happy - Logan LaPlante - TEDxUniversityotNevada. [online]. Режим доступу: http://www.voutube.com/watch?v=TPzSsDoiwM8 [дата останнього звернення 22.07.2019]

\section{REFERENCE}

Shkilnyi sad za. [The School Garden for]. [online]. Rezhym dostupu: http://manjsvita.org,ua/news/shkilniy-sad-za [data ostannoho zvernennia 20.07.2019] (in Ukrainian)

Shkilnyi sad u Ripkakh: uchni shkoly No2 zaklaly hriadky, na yakykh sami vyroshchuvatymut ovochi. [School Garden in Ripky: Students of School No 2 Have Laid Plots Where They Will Grow Vegetables Themselves]. [online]. Rezhym dostupu: https://cn.suspilne.media/news/17760 (in Ukrainian)

Znamirovska, N. (2012). Shkilnyi sad yak navchalno-doslidnytske seredovyshche suchasnoi shkoly: Polskyi dosvid [School Garden as an Educational and Research 
Environment of Modern School: Polish Experience]. N. Znamirovska, M. Znamirovskyi. Postmetodyka. No 2. S. 22-25. [online]. Rezhym dostupu: http://nbuv.gov.ua/UJRN/. Postmetodyka_2012_2_6. (in Ukrainian)

Vygotskiy, L. S. Sobraniye sochineniy v $6 t$. T. 4. Detskaya psikhologyiya [Collections of Works in 6 vol. Vol 4. Children Psychology]. [pod red. D.B. Elkonina]. Moskva, 1984. 432 s. (in Russian)

Prykhodko, Kateryna. (2010). Seredovyshchnyi pidkhid do navchannia i vykhovannia molodi [Environment Approach to Education and Upbringing of Youth]. Shliakh osvity. No3. S.22-27. (in Ukrainian)

Sukhomlynskyi, V. (1963). Sad dlia liudei [Garden for People]. Rad. Ukraina. 20 berez. (in Ukrainian)

Sukhomlynskyi, V. (1964). Zrostut kvity dyvnoi krasy [Flowers of Amazing Beauty Will Grow]. Kirovohr. pravda. 1 sich. (in Ukrainian)

Sukhomlynskyi, V. (1969). Stezhka do kvituchoho sadu [The Parth to the Flowering Garden]. Lit. Ukraina. 26 veres. (in Ukrainian)

Sukhomlynskyi, V. (1977). Pavlyska serednia shkola. Vybrani tvory: V 5 t. T. 4. [Pavlysh Secondary School: Selected Works: in 5 vol. Vol 4.]. Kyiv : Rad. Shk. S.7-390. (in Ukrainian)

Sukhomlynskyi, V. Sertse viddaiu ditiam: [nove prochytannia] [I Give my Heart to Children: New Reading]. uklad. ta avt. vstup. st. "U poshukakh spravzhnoho", s. 5-22, O. V. Sukhomlynska] (2012). [Kharkiv] : Akta. 537 s. (in Ukrainian)

Sukhomlynskyi, V. Ya rozpovim vam kazku... Filosofiia dlia ditei [I'll Tell You a Fairytale... Philosophy for children]. Vasyl Sukhomlynskyi ; uklad. Sukhomlynska O. V. (2018). Kharkiv: VD "ShKOLA". 576 s. (in Ukrainian)

Novyi osvitnii prostir $=$ symvoly zmin $[\mathrm{New}$ educational space $=$ symbols of changers] Rekomendatsii. [online]. Rezhym dostupu: http:/mon.gov.ua/storage/app/media/ zagalna\%20serednya/nop/5noprekomend22.pdf [data ostannoho zvernennia 20.07.2019] (in Ukrainian)

Hackschooling Makes Me Happy - Logan La Plante - TEDxUniversityofNevada. [online]. Rezhym dostupu: https://www.youtube.com/watch?v=TPzSsDoiwM8 (in English)

\title{
SCHOOL GARDEN AS A COMPONENT OF EDUCATIONAL ENVIRONMENT AT SUKHOMLYNSKYI SCHOOL
}

\author{
Lesia Sukhomlynska \\ Reseacher at the Sukhomlynskyi State National Pedagogical Library, \\ Kyiv, Ukraine \\ ORCID: 0000-0003-3055-53 \\ e-mail: 1408koala@gmail.com
}

\begin{abstract}
In the article the concept of "educational environment" through the prism of the research topic has been characterised; the school garden as an important component in the structure of the pedagogical system of V. Sukhomlynskyi has singled out. It has been found that the school garden appears as a symbol of the school in general, and especially of the school headed by Sukhomlynskyi, and is nominated by the teacher as the center of the educational environment in which students live and develop. The content of the concept "school garden" is disclosed, which, according to Sukhomlynskyi, includes the garden itself as an organized area with fruit trees and shrubs, as well as a school and research sites, a green laboratory, beds, greenhouses etc. It is proved that at Sukhomlynskyi school the school garden was used to develop and more productive improvement of physical, moral, mental, labor, aesthetic upbringing of students of different ages and genders, the content of each direction is clarified, the used forms and methods of teaching and upbringing are outlined. It has been concluded the multifunctionality of the phenomenon of the "school garden" at the
\end{abstract}


Sukhomlynskyi School, which, depending on the context, acts as a complex method of education and training, a kind of organization of the pedagogical process, with the purpose of the educational process, an idealized ideal, for which pedagogical harmony is applied.

The analysis was conducted through the prism of the goals and objectives of the New Ukrainian School as an additional important argument and resource for the development of a child-friendly, natural, educational and educational environment.

Keywords: V. Sukhomlynskyi, educational environment, school garden, Pavlysh school, education, upbringing, New Ukrainian School.

Стаття надійшла до редакиії 08.08.2019 p. 